\title{
ANALISIS RISIKO PRODUKSI PADI DAN PENDAPATAN RUMAH TANGGA PETANI PADI DI KAMPUNG SIMPANG ASAM KECAMATAN BANJIT KABUPATEN WAY KANAN
}

\author{
(The Analysis of Rice Production Risk and Income of Farmer Households in Simpang Asam Village \\ Banjit Subdistrict Way Kanan Regency)
}

Devira Nurani Sejati, Zainal Abidin, Teguh Endaryanto

Jurusan Agribisnis, Fakultas Pertanian, Universitas Lampung, Jl. Prof. Dr. Soemantri Brodjonegoro No. 1 Bandar Lampung 35145, E-mail: zainal.abidin@fp.unila.ac.id

\begin{abstract}
This study aims to analyze the risk of rice production and income of rice farmer households in Simpang Asam Village Banjit District Way Kanan Regency. This study is a survey involving 65 farmers who were selected by using simple random sampling. The primary and secondary data were collected from February to April 2018. The rice production risk is analyzed by calculating variances, standard deviations, and variance coefficients. Household income of rice farmers are obtained from the calculation of income from main farming activity, other farming activities, and non farming activities. The results showed that the production risk was considered in a low category with $C V$ value of. 023. Farmer households income was IDR43,694,613.85, coming from main farming 43.04 percent, other farming 39.25 percent, and non farming activities 17.70 percent.
\end{abstract}

Key words: household income, rice farmers, risk of rice production

\section{PENDAHULUAN}

Provinsi Lampung merupakan salah satu sentra produksi padi nasional. Berdasarkan Kementerian Pertanian Republik Indonesia (2016), Lampung merupakan daerah di luar Pulau Jawa penghasil padi terbesar di Indonesia setelah Sumatera Utara dan Sumatera Selatan dengan poduksi sebesar 3.496.489 ton GKP pada tahun 2015. Angka produksi tersebut mengalami peningkatan selama 2012-2014. Kabupaten Way Kanan merupakan wilayah yang memproduksi padi sawah dengan sistem pengairan irigasi teknis di Provinsi Lampung. Berdasarkan BPS Way Kanan (2017), Kabupaten Way Kanan mengalami fluktuasi produksi dari tahun 2010-2015.

Fluktuasi produksi padi ini mengindikasi adanya risiko produksi yang dihadapi oleh petani. Hasil penelitian Pangaribuan (2016), risiko produksi ini salah satunya disebabkan oleh penggunaan faktor produksi yang tidak tepat jumlah dan waktu penggunaannya. Demikian pula dengan hasil penelitian Sarianti (2012) yang menunjukkan bahwa risiko produksi bersumber dari proses produksi yang masih belum mengikuti standar operasional prosedur yang telah ditetapkan dan risiko dari faktor eksternal seperti perubahan iklim yang dapat mengakibatkan munculnya hama dan penyakit.
Risiko produksi berpengaruh terhadap hasil panen yang dapat merugikan petani. Berdasarkan informasi survei yang diperoleh dari UPT Pertanian Kecamatan Banjit, hasil produksi yang diterima petani dengan risiko produksi normal sebesar 6-7 ton (GKP) per musim tanam, sedangkan hasil produksi yang diterima petani dengan risiko produksi hama dan penyakit tanaman lebih dari ambang batas ekonomi sebesar 4-5 ton (GKP) per musim tanam.

Hasil panen yang berfluktuasi akan mengakibatkan pendapatan usahatani padi petani juga mengalami fluktuatif. Besar kecilnya pendapatan dalam usahatani dipengaruhi oleh penerimaan (hasil produksi) dan pengeluaran (biaya produksi), sehingga apabila penerimaan berubah, maka pendapatan yang diterima petani juga berubah (Lumintang 2013).

Perbedaan hasil yang diperoleh petani akan mempengaruhi ketersediaaan pangan rumahtangga petani yang akan berdampak pada ketahanan pangan rumah tangga petani. Sebagian besar petani padi sawah termasuk ke dalam kategori petani subsisten, karena dalam kegiatan usahataninya petani tidak hanya bertujuan untuk menjual, namun juga untuk memenuhi kebutuhan pangan rumah tangganya. 
Petani padi sawah dihadapkan pada risiko produksi yang menyebabkan fluktuasi produksi di setiap musim tanam dan belum diketahui berapa besar risiko produksi yang dialami oleh petani akan berdampak pada ketidakpastian pendapatan petani dari usahatani tersebut. Oleh sebab itu, penelitian ini bertujuan untuk menganalisis risiko produksi dan pendapatan rumah tangga petani padi sawah di Kampung Simpang Asam Kecamatan Banjit Kabupaten Way Kanan.

\section{METODE PENELITIAN}

Penelitian ini dilakukan di Kecamatan Banjit, Kabupaten Way Kanan dengan menggunakan metode survei. Lokasi penelitian dipilih secara sengaja (purposive) dengan pertimbangan bahwa kecamatan tersebut penghasil produksi pangan padi terbesar di Kabupaten Way Kanan. Populasi penelitian adalah seluruh petani padi sawah di Kampung Simpang Asam dengan jumlah petani sebesar 479 jiwa. Kampung Simpang Asam dipilih secara purposive. Responden penelitian petani padi sawah dipilih secara acak (simple random sampling) dengan menggunakan tabel bilangan acak.

Penentuan ukuran sampel dilakukan dengan menggunakan rumus perhitungan sampel mengacu pada Issac dan Michael dalam Sugiarto (2003).

$$
\mathrm{n}=\frac{\mathrm{NZ}^{2} \mathrm{~S}^{2}}{\mathrm{Nd}^{2}+\mathrm{Z}^{2} \mathrm{~S}^{2}}
$$

Keterangan :

$\mathrm{n} \quad=$ jumlah sampel

$\mathrm{N} \quad=$ jumlah populasi

$\mathrm{S}^{2} \quad=$ variasi sampel $(5 \%=0,05)$

$\mathrm{Z}=$ distribusi $\mathrm{Z}(95 \%=1,96)$

$\mathrm{D} \quad=$ simpangan baku $(5 \%=0,05)$

Berdasarkan hasil perhitungan sampel yang diperoleh jumlah responden petani di daerah penelitian sebanyak 65 orang di Kampung Simpang Asam. Waktu pengambilan data dilakukan pada Februari 2018-April 2018.

Analisis data yang digunakan dalam penelitian ini adalah analisis deskriptif kuantitatif. Analisis data dalam penelitian ini meliputi analisis risiko, analisis produksi dan analisis pendapatan rumah tangga. Menurut Kadarsan (1995), analisis risiko produksi dapat diketahui dengan menghitung nilai yang diharapkan atau hasil rata-rata, ragam, simpangan baku koefisien varians, dan batas bawah. Ukuran untuk hasil yang diharapkan adalah hasil rata-rata atau mean, rumusnya yaitu:

$$
\mathrm{E}=\frac{\sum_{1=1}^{\mathrm{n}} \mathrm{E}_{\mathrm{i}}}{\mathrm{n}} \ldots \ldots \ldots \ldots \ldots \ldots
$$

Keterangan:

$\mathrm{E}=$ nilai rata-rata hasil yang diharapkan (mean)

$\mathrm{Ei}=$ hasil bersih per hektar pada tahun ke-1

$\mathrm{n}=$ jumlah pengamatan

Ukuran rumus ragam adalah sebagai berikut:

$$
\mathrm{V}^{2}=\frac{\sum_{\mathrm{i}=1}^{\mathrm{n}}\left(\mathrm{E}_{\mathrm{i}}-\mathrm{E}\right)^{2}}{(\mathrm{n}-1)} \ldots \ldots \ldots \ldots
$$

Simpangan baku merupakan akar dari ragam, atau secara matematis dapat ditulis sebagai berikut:

$$
\mathrm{V}=\frac{\sqrt{\sum_{\mathrm{i}=1}^{\mathrm{n}}(\mathrm{Ei}-\mathrm{E})^{2}}}{(\mathrm{n}-1)} \ldots \ldots \ldots \ldots
$$

Keterangan :

$$
\begin{array}{ll}
\mathrm{V}^{2} & =\text { ragam } \\
\mathrm{V} & =\text { simpangan baku } \\
\mathrm{E} & =\text { rata-rata hasil yang diharapkan } \\
\mathrm{Ei} & =\text { hasil yang diharapkan pada periode ke- } \mathrm{i} \\
\mathrm{n} & =\text { jumlah periode pengamatan }
\end{array}
$$

Untuk memilih alternatif yang memberikan risiko paling sedikit dalam mengharapkan suatu hasil dapat dipakai keuntungan koefisien variasi yang rumusnya adalah :

$$
(\mathrm{V} 14) \frac{\mathrm{V}}{\mathrm{E}}
$$

Keterangan:

$$
\begin{array}{ll}
\mathrm{V} & =\text { simpangan baku } \\
\mathrm{E} & =\text { hasil rata-rata }(\text { mean })
\end{array}
$$

Besarnya nilai koefisien variasi menunjukkan besarnya risiko yang dihadapi oleh petani. Nilai koefisien variasi usahatani kecil, maka karakteristik usahatani memiliki risiko rendah. Sebaliknya, jika nilai koefisien variasi usahatani besar, maka karakteristik usahatani memiliki risiko besar.

Batas bawah (L) menunjukkan nilai terendah pendapatan yang mungkin diterima oleh petani. Rumus perhitungan batas bawah (L) adalah:

$$
\mathrm{L}=\mathrm{E}-2 \mathrm{~V} \text {. }
$$

Keterangan:

$\mathrm{L}=$ batas bawah

$\mathrm{E}=$ rata-rata hasil yang diharapkan

$\mathrm{V}=$ simpangan baku 
Analisis pendapatan dengan menghitung pendapatan usahatani utama (padi sawah), pendapatan usahatani lain, dan pendapatan di luar pertanian. Pendapatan usahatani padi juga dapat dihitung menggunakan rumus (Soekartawi 1995).

$$
\begin{aligned}
& \pi=\mathrm{TR}-\mathrm{TC} \\
& \pi=\mathrm{Y} . \mathrm{Py}-\mathrm{Xi} . \mathrm{Pxi}
\end{aligned}
$$

Keterangan :

$\pi \quad=$ pendapatan

$\mathrm{TR}=$ total revenue (total penerimaan)

$\mathrm{TC}=$ total cost (total biaya)

$\mathrm{Y} \quad=$ produksi $(\mathrm{kg})$

Py $\quad=$ harga hasil produksi $(\mathrm{Rp})$

$\mathrm{Xi} \quad=$ faktor produksi, $\mathrm{i}=1,2,3,4, \ldots \ldots, \mathrm{n}$

Pxi $=$ harga faktor produksi $(\mathrm{Rp})$

Pendapatan rumah tangga petani merupakan pendapatan yang diperoleh dari penjumlahan pendapatan usahatani utama dengan pendapatan yang berasal dari usahatani lain dan pendapatan luar usahatani (Rahim dan Astuti 2008).

$\mathrm{Y}_{\text {total }}=\mathrm{Y}_{\text {usahatani utama }}+\mathrm{Y}_{\text {usahatani lain }}+\mathrm{Y}_{\text {luar pertanian } \ldots}$

Keterangan:

$Y_{\text {total }}=$ total pendapatan rumah tangga

$\mathrm{Y}_{\text {usahatani utama }} \quad=$ pendapatan dari usahatani utama

$\mathrm{Y}_{\text {usahatani lain }} \quad=$ pendapatan dari usahatani lain

$\mathrm{Y}_{\text {luar pertanian }} \quad=$ pendapatan usahatani luar pertanian

\section{HASIL DAN PEMBAHASAN}

\section{Karakteristik Responden}

Rata-rata umur kepala keluarga dan ibu rumah tangga berada pada umur 40-54 tahun. Tingkat pendidikan kepala rumah tangga petani dan ibu rumah tangga rata-rata berada pada tingkat pendidikan SMA. Sebanyak 52 persen rumah tangga memiliki jumlah anggota keluarga 3-4 jiwa. Sebanyak 43,07 persen petani memiliki pengalaman usahatani 24-35 tahun yang berarti petani padi berpengalaman dalam mengelola usahataninya. Sebanyak 66,15 persen kepala keluarga dan 70,76 persen ibu rumah tangga petani padi tidak memiliki pekerjaan sampingan. Hal ini membuktikan bahwa pekerjaan utama untuk memenuhi kebutuhan pangan adalah dengan berusahatani padi.

Rata-rata luas lahan petani yaitu 0,94 ha. Sebanyak 49,23 persen status kepemilikan lahan merupakan lahan milik sendiri. Petani pemilik melakukan kegiatan usahatani dengan cara menggarap sendiri lahan usahataninya. Modal yang digunakan oleh petani dalam berusahatani diperoleh dari berbagai sumber modal. Petani pemilik menggunakan modal sendiri atau menggunakan modal dari pekerjaan sampingan. Petani penggarap memperoleh modal dari pinjaman tengkulak beras yang menyediakan pupuk dengan pembayaran secara ijon.

\section{Penggunaan Sarana Produksi}

Sarana produksi yang digunakan meliputi benih, pupuk, pestisida, dan tenaga kerja. Perincian penggunaan sarana produksi musim tanam 1 (MT1) dan 2 (MT2) per hektar dapat dilihat pada Tabel 1. Varietas padi yang banyak digunakan oleh petani pada MT1 dan MT2 adalah varietas IR64. Pada MT2 merupakan musim kemarau terjadi peningkatan penggunaan benih padi IR-64 yang menyebabkan petani lebih memilih menggunakan benih IR-64, karena memiliki umur yang genjah, sehingga tidak membutuhkan air yang banyak. Pemilihan varietas benih padi akan mempengaruhi produksi padi yang dihasilkan oleh petani.

Petani menggunakan dua jenis pupuk yaitu pupuk tunggal dan pupuk majemuk. Pupuk tunggal yang digunakan oleh petani berupa pupuk Urea, SP-36, dan $\mathrm{KCl}$ (non subsidi). Pupuk majemuk yang digunakan oleh petani antara lain NPK phonska, sampurna daun dan buah, $\mathrm{KCl}$ cair, gandasil daun dan buah serta pomi. Petani memperoleh pupuk dari kios pertanian dan pabrik penggilingan padi. Harga jual pupuk di kios-kios pertanian lebih murah dibandingkan dengan harga jual pupuk di pabrik penggilingan padi. Tabel 1 menunjukkan penggunaan pupuk tunggal (SP36, Urea, dan Phonska) pada MT1 lebih tinggi dibandingkan dengan dengan penggunaan pupuk pada MT2.

Pada Tabel 1, pestisida yang digunakan oleh petani pada MT1 sebesar Rp480.752,86 dan MT2 sebesar Rp540.124,39 lebih besar dibandingkan dengan penggunaan pestisida pada MT2. Hal ini diketahui pada MT2, petani mengalami serangan hama dan penyakit yaitu wereng dan blast. Salah satu cara yang digunakan petani untuk membasmi hama dan penyakit dengan menggunakan pestisida.

Tenaga kerja yang digunakan oleh petani terdiri dari dua tenaga kerja yaitu tenaga kerja dalam keluarga (TKDK) dan tenaga kerja luar keluarga (TKLK). Tenaga kerja dihitung dengan menggunakan satuan hari kerja pria (HKP). 
Tabel 3. Rata-rata pendapatan dan biaya usahatani padi sawah di Kampung Simpang Asam Kecamatan Banjit

\begin{tabular}{|c|c|c|c|c|c|c|c|}
\hline \multirow{2}{*}{ No } & \multirow{2}{*}{ Uraian } & \multicolumn{3}{|c|}{ MT1 (Hujan) } & \multicolumn{3}{|c|}{ MT2 (Kemarau) } \\
\hline & & Jumlah & Harga (Rp) & Nilai (Rp) & Jumlah & Harga (Rp) & Nilai (Rp) \\
\hline \multirow[t]{2}{*}{1} & Penerimaan & & & & & & \\
\hline & Produksi Padi & $5.099,84$ & $4.209,23$ & $21.466 .388,01$ & $2.944,35$ & $4.612,31$ & $13.580 .264,38$ \\
\hline \multirow[t]{29}{*}{2} & Biaya Produksi & & & & & & \\
\hline & I. Biaya Tunai & & & & & & \\
\hline & Benih Ciherang (kg) & 7,12 & $13.560,00$ & $96.540,10$ & 2,86 & $13.583,33$ & $38.904,80$ \\
\hline & Benih IR64 (kg) & 13,58 & $14.594,59$ & $198.257,18$ & 14,98 & $14.285,71$ & $213.935,00$ \\
\hline & Benih Mapan (kg) & 0,08 & $150.000,00$ & $12.274,96$ & 0,00 & 0,00 & 0,00 \\
\hline & Benih Mekongga (kg) & 0,98 & $13.666,67$ & $13.420,62$ & 4,09 & $13.909,09$ & $56.911,17$ \\
\hline & Pupuk SP36 (kg) & 169,39 & $3.233,90$ & $547.804,38$ & 185,76 & $3.113,11$ & $578.295,46$ \\
\hline & Pupuk Urea (kg) & 234,86 & $2.258,46$ & $530.424,27$ & 220,13 & $2.166,15$ & $476.837,47$ \\
\hline & Primatan Padi & 0,39 & $25.000,00$ & $9.819,97$ & 0,47 & $50.000,00$ & $23.731,59$ \\
\hline & Pupuk Phonska (kg) & 153,85 & $3.563,16$ & $548.178,14$ & 169,39 & $3.234,92$ & $547.977,55$ \\
\hline & Pomi (liter) & 0,18 & $40.000,00$ & $7.201,31$ & 0,20 & $40.000,00$ & $7.855,97$ \\
\hline & Pupuk KCl Cair (liter) & 0,10 & $50.000,00$ & $4.909,98$ & 0,11 & $50.000,00$ & $5.319,15$ \\
\hline & Pupuk KCl (kg) & 4,17 & $6.250,00$ & $26.084,29$ & 4,42 & $6.750,00$ & $29.828,15$ \\
\hline & Sampurna Daun (kg) & 0,32 & $16.000,00$ & $5.106,38$ & 0,26 & $16.000,00$ & $4.189,85$ \\
\hline & Sampurna Buah (kg) & 0,32 & $16.000,00$ & $5.106,38$ & 0,26 & $16.000,00$ & $4.189,85$ \\
\hline & Gandasil Daun (kg) & 0,29 & $70.000,00$ & $20.621,93$ & 0,26 & $70.000,00$ & $18.330,61$ \\
\hline & Gandasil Buah(kg) & 0,29 & $70.000,00$ & $20.621,93$ & 0,23 & $70.000,00$ & $16.039,28$ \\
\hline & Pestisida (liter) & & & $480.752,86$ & & & $540.124,39$ \\
\hline & TK Luar Keluarga (HKP) & 89,47 & $60.000,00$ & $5.368 .412,44$ & 73,03 & $60.000,00$ & $4.382 .078,56$ \\
\hline & Pajak (Rp/th) & & & $18.052,37$ & & & $18.052,37$ \\
\hline & Biaya Karung & & & $55.400,98$ & & & $53.027,82$ \\
\hline & Biaya Tali Rafia & & & $14.484,45$ & & & $14.484,45$ \\
\hline & Total Biaya Tunai & & & $7.983 .474,93$ & & & $7.030 .113,50$ \\
\hline & II. Biaya diperhitungkan & & & & & & \\
\hline & TK Dalam Keluarga (HKP) & 8,41 & $60.000,00$ & $504.807,69$ & 13,86 & $60.000,00$ & $831.812,60$ \\
\hline & Penyusutan Alat (Rp/MT) & & & $633.632,02$ & & & $633.632,02$ \\
\hline & Sewa Lahan & & & $5.990 .180,03$ & & & $5.990 .180,03$ \\
\hline & Total Biaya diperhitungkan & & & $1.138 .439,72$ & & & $1.465 .444,63$ \\
\hline & III. Total Biaya & & & $9.121 .914,65$ & & & $8.495 .558,13$ \\
\hline \multirow[t]{3}{*}{3} & Pendapatan & & & & & & \\
\hline & I. Pendapatan atas Biaya Tunai & & & $13.482 .913,08$ & & & $6.550 .150,88$ \\
\hline & II. Pendapatan atas Biaya Total & & & $12.344 .473,37$ & & & $5.084 .706,26$ \\
\hline \multirow[t]{3}{*}{4} & R/C Rasio & & & & & & \\
\hline & I. $\mathrm{R} / \mathrm{C}$ atas Biaya Tunai & & & 2,69 & & & 1,93 \\
\hline & II. R/C atas Biaya Total & & & 2,35 & & & 1,60 \\
\hline
\end{tabular}

Rata-rata penggunaan tenaga kerja terbesar pada MT1 dan MT2 adalah kegiatan pengolahan lahan, penanaman, penyiangan, dan pemanenan. Tiga kegiatan tersebut dilakukan dengan sistem borongan dan tenaga kerjanya rata-rata berasal dari luar keluarga.

\section{Produksi dan Risiko Produksi Usahatani Padi}

Produksi yang dianalisis pada penelitian ini adalah produksi padi dalam setahun atau dua kali musim tanam. Pada MT1 bulan Desember sampai Maret 2016-2017 merupakan produksi padi musim hujan atau musim rendeng dan MT2 bulan Agustus sampai November 2016-2017 merupakan produksi musim kemarau atau musim gadu. Penerimaan diperoleh dari perkalian produksi padi dengan harga jual. Produksi padi yang digunakan merupakan produksi padi Gabah Kering Panen (GKP). Semakin tinggi produksi dan harga jual, maka akan semakin tinggi penerimaan yang akan diterima oleh petani padi.

Tabel 2 dapat dilihat bahwa produksi MT1 sebesar 4.793,85 kg/ha dan produksi MT2 sebesar 2.767,69 $\mathrm{kg} / \mathrm{ha}$. Hal tersebut menunjukkan produksi padi MT1 pada musim hujan lebih tinggi daripada produksi padi MT2 musim kemarau, ini terjadi karena pada MT2 tanaman padi petani diserang hama dan penyakit seperti hama wereng cokelat dan penyakit blast. Penurunan produksi yang terjadi pada MT 2 di daerah penelitian terjadi juga dengan hasil penelitian yang dilakukan oleh Nopralita, Abidin, dan Affandi (2017) dengan responden petani padi sawah dekat irigasi dan jauh irigasi, petani padi yang dekat irigasi mengalami 
Tabel 2. Rata-rata produksi dan penerimaan petani padi di Kampung Simpang Asam Kecamatan Banjit, tahun 2018

\begin{tabular}{lr}
\hline \multicolumn{1}{c}{ Uraian } & \multicolumn{1}{c}{ Per hektar } \\
\hline MT1(Hujan) & \\
Produksi (Kg) & $5.099,84$ \\
Harga (Rp/Kg) & $4.209,23$ \\
Penerimaan (Rp) & \\
\hline MT2 (Kemarau) & $2.946 .388,01$ \\
Produksi (Kg) & $4.612,31$ \\
Harga (Rp/Kg) & $13.580 .264,38$ \\
Penerimaan (Rp) &
\end{tabular}

penurunan produksi padi pada MT 2 yang merupakan musim EL Nino (kemarau) sebesar 8,32 persen. Hal serupa terjadi karena petani padi dekat irigasi lebih banyak mengalami serangan penyakit blast yang dapat membuat kerusakan batang padi. Risiko produksi berasal dari faktor internal dan faktor eksternal. Risiko produksi yang dominan ditemukan di daerah penelitian berasal dari risiko produksi eksternal yaitu serangan hama dan penyakit. Hama dan penyakit yang menyerang antara lain wereng cokelat, tikus, sundep, blast, patah leher, burung gereja, dan ulat grayak.

Penilaian risiko produksi dihitung produksi per petani selama lima musim tanam terakhir tanam terakhir. Produksi padi lima musim tanam dapat dilihat pada gambar 1 .

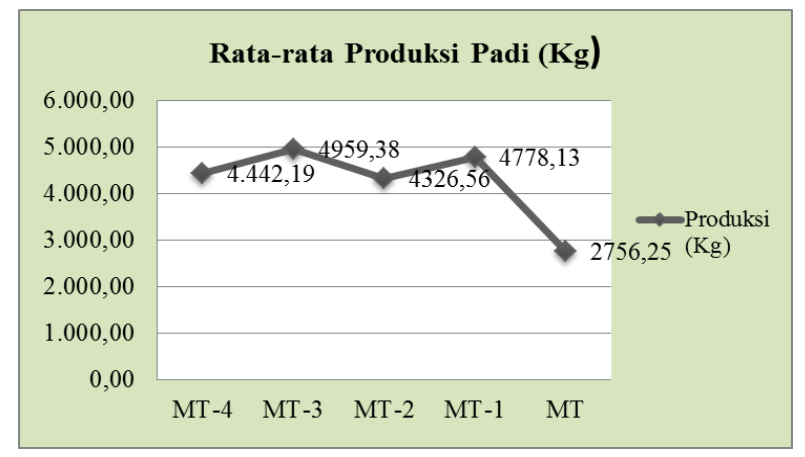

Gambar 1. Fluktuasi produksi padi sawah selama lima musim tanam terakhir per hektar petani di Kampung Simpang Asam Kecamatan Banjit

Untuk mengetahui alternatif yang memberikan risiko paling sedikit dalam mengharapkan suatu hasil dapat dipakai ukuran keuntungan koefisien variasi. Nilai koefisien variasi usahatani kecil, maka karakteristik usahatani memiliki risiko rendah. Sebaliknya, jika nilai koefisien variasi usahatani besar, maka karakteristik usahatani memiliki risiko besar.
Tabel 3. Rata-rata risiko produksi usahatani padi per usahatani dan per hektar di Kampung Simpang Asam Kecamatan Banjit, tahun 2018

\begin{tabular}{lr}
\hline \multicolumn{1}{c}{ Keterangan } & Per hektar \\
\hline Mean (E) & $4.532,24$ \\
Simpangan Baku (V) & 996,02 \\
Koefisien Variasi (CV) & 0,23 \\
Batas Bawah (L) & $2.540,20$ \\
\hline Sumber: Data Diolah, 2018
\end{tabular}

Tabel 3 diperoleh informasi rata-rata produksi (E) yang diterima petani per hektar sebesar 4.532,24 $\mathrm{kg} / \mathrm{ha}$. Nilai simpangan baku (V) per hektar sebesar 996,02 dan nilai koefisien variasi (CV) per hektar sebesar 0,23 serta nilai batas bawah (L) per hektar sebesar $2.540,20 \mathrm{~kg} / \mathrm{ha}$. Hal ini menunjukan bahwa nilai $\mathrm{CV}$ kurang dari 0,50 bahwa risiko yang diterima petani rendah dengan nilai batas bawah produksi yang mungkin diterima petani sebesar 2.540,20 kg/ha. Hal ini sejalan dengan penelitian yang dilakukan oleh Indah, Zakaria, dan Prasmatiwi (2013), peluang risiko produksi yang dialami petani padi irigasi teknis dengan nilai CV sebesar 0,27 dan nilai CV petani padi tadah hujan sebesar 0,15 . Meskipun sama-sama memiliki nilai CV kurang dari 0,50 akan tetapi terdapat perbedaan dimana nilai $\mathrm{CV}$ produksi padi irigasi teknis lebih tinggi dibandingkan dengan nilai $\mathrm{CV}$ petani lahan tadah hujan, karena petani padi irigasi teknis memiliki produksi yang lebih fluktuatif.

\section{Pendapatan Usahatani Padi}

Pendapatan usahatani padi sawah dihitung dalam satu tahun (dua kali musim tanam). Pendapatan usahatani padi diperoleh dari selisih antara total penerimaan dengan total biaya usahatani padi. Penerimaan usahatani merupakan hasil perkalian antara harga jual dengan jumlah produksi. Biaya usahatani dibagi menjadi dua yaitu biaya tunai dan biaya diperhitungkan.

Tabel 1 menunjukkan pendapatan usahatani petani padi di Kampung Simpang Asam Kecamatan Banjit memiliki rata-rata pendapatan atas biaya tunai tertinggi pada MT1 musim hujan sebesar Rp13.521.052,50 per hektar. Jika dibandingkan dengan pendapatan usahatani padi pada MT2 musim kemarau sebesar Rp6.556.211,83 per hektar, maka pendapatan petani mengalami penurunan yang cukup signifikan yaitu selisih penurunan pendapatan sebesar Rp6.964.840,67 per hektar. Penurunan pendapatan dikarenakan pada musim kemarau tanaman padi petani mengalami serangan hama wereng cokelat yang 
dapat mengganggu pertumbuhan dan perkembangan tanaman padi.

Perbandingan penerimaan dengan biaya (rasio $\mathrm{R} / \mathrm{C}$ ) ini terdiri dari rasio $\mathrm{R} / \mathrm{C}$ total yang merupakan rasio antara penerimaan total rata-rata dengan biaya total rata-rata dan rasio $\mathrm{R} / \mathrm{C}$ tunai yang merupakan rasio antara penerimaan total dengan biaya tunai rata-rata. Berdasarkan nilai $\mathrm{R} / \mathrm{C}$ rasio tunai kedua musim tanam, usahatani padi sawah di Kampung Simpang Asam Kecamatan Banjit menunjukkan bahwa usahatani padi sawah memberikan keuntungan.

\section{Pendapatan Rumah Tangga Petani}

Pendapatan rumah tangga petani padi dihitung dari rata-rata penjumlahan pendapatan usahatani utama, pendapatan usahatani lain dan pendapatan luar pertanian dalam satu tahun. Pendapatan usahatani lain diperoleh dari menanam komoditas seperti jagung, kopi, lada, karet, kakao, sayuran, pisang dan berternak sapi maupun kambing. Rata-rata pendapatan yang diperoleh petani responden dari kegiatan usahatani lain dapat dilihat pada Tabel 4.

\section{Pendapatan usahatani lain}

Rata-rata pendapatan rumah tangga petani padi terbesar selain usahatani padi berasal dari usahatani kopi dengan jumlah pendapatan sebesar Rp9.035.076,92 per tahun (52,67 persen). Usahatani kopi merupakan usahatani perkebunan tanaman tahunan yang umumnya berumur lebih dari satu tahun dan pemungutan hasilnya dilakukan lebih dari satu kali masa panen untuk satu kali pertanaman.

Tabel 4. Rata-rata pendapatan yang diperoleh petani dari kegiatan usahatani lainnya di Kampung Simpang Asam Kecamatan Banjit, Tahun 2018

\begin{tabular}{lrr}
\hline \multicolumn{1}{c}{ Sumber pendapatan } & \multicolumn{1}{c}{$\begin{array}{c}\text { Pendapatan } \\
\text { (Rp/tahun) }\end{array}$} & \multicolumn{1}{c}{$(\%)$} \\
\hline Usahatani jagung & $1.752 .307,69$ & 10,22 \\
Usahatani kopi & $9.035 .076,92$ & 52,67 \\
Usahatani lada & $193.846,15$ & 1,74 \\
Usahatani karet & $969.230,77$ & 5,65 \\
Usahatani kakao & $39.076,92$ & 0,23 \\
Usahatani sayuran & $319.461,54$ & 1,86 \\
Usahatani pisang & $146.000,00$ & 0,85 \\
Usahatani ternak kambing & $1.154 .615,38$ & 6,73 \\
Usahatani ternak sapi & $3.398 .461,54$ & 19,81 \\
Usahatani pekarangan & $42.000,00$ & 0,24 \\
\hline Jumlah & $17.154 .076,92$ & 100,00 \\
\hline Sumber: data diolah, 2018 & &
\end{tabular}

Sumber: data diolah, 2018
Lahan kopi yang dimiliki petani terdiri dari beberapa persil ada yang terletak di sekitar Kampung Simpang Asam atau sering disebut sebagai lahan kopi marga dan ada juga ada yang terletak di kawasan hutan kemasyarakatan di sepanjang Bukit Barisan dan Bukit Pesagi. Pendapatan terendah diperoleh dari kegiatan usahatani kakao berkisar Rp39.076,92 per tahun dengan persentase sebesar 0,23 persen. Selain itu, petani memiliki ternak sapi dan kambing dengan rata-rata pendapatan berkisar Rp3.398.461,54 per tahun dan Rp1.154.615,38 per tahun dengan persentase masing-masing sebesar 19,81 persen dan 6,73 persen. Petani melakukan kegiatan berternak kambing dan sapi untuk memperoleh tambahan pendapatan. Pola pemeliharaan ternak yang dilakukan di Kampung Simpang Asam didominasi dengan usaha peternakan berskala kecil dengan karakteristik rata-rata kepemilikan ternak rendah, sebagai tabungan hidup, pemeliharaan dikandangkan di belakang rumah, dan pemberian pakan berupa rumput yang ada di sekitar rumah dan perkebunan.

\section{Pendapatan luar pertanian}

Petani memiliki sumber pendapatan luar pertanian sebagai pegawai honorer, karyawan toko, penjahit, wirasawasta, buruh non petanian sewa traktor, PNS, dan industri makanan. Berdasarkan hasil penelitian, rumah tangga memiliki sumber pendapatan dari berbagai pekerjaan yang terdiri dari pekerjaan sampingan kepala keluarga dan pekerjaan sampingan ibu rumah tangga. Rata-rata total pendapatan luar pertanian rumah tangga petani padi per tahun sebesar Rp7.734.000,00. Pendapatan luar pertanian tertinggi bersumber dari kegiatan menjadi pedagang sebesar Rp1.486.153,85 untuk kepala keluarga dan sebesar Rp2.984.615,38 untuk pendapatan ibu rumah tangga.

Tabel 5. Rata-rata pendapatan rumah tangga petani padi dalam satu tahun di Kampung Simpang Asam, Kecamatan Banjit, tahun 2018

\begin{tabular}{clcc}
\hline No & \multicolumn{1}{c}{$\begin{array}{c}\text { Sumber } \\
\text { Pendapatan }\end{array}$} & $\begin{array}{c}\text { Pendapatan } \\
\text { (Rp/thn) }\end{array}$ & $(\%)$ \\
\hline 1 & $\begin{array}{l}\text { Pendapatan } \\
\text { usahatani padi }\end{array}$ & $18.806 .536,92$ & 43,04 \\
2 & $\begin{array}{l}\text { Pendapatan } \\
\text { usahatani lain }\end{array}$ & $17.154 .076,92$ & 39,25 \\
3 & $\begin{array}{l}\text { Pendapatan } \\
\text { luar pertanian }\end{array}$ & $7.734 .000,00$ & 17,70 \\
\hline & Jumlah & $43.694 .613,85$ & 100,00 \\
\hline
\end{tabular}

Sumber: data diolah, 2018 
Wiraswasta yang dilakukan oleh rumah tangga petani menjadi pedagang sembako dan makanan ringan. Pendapatan luar pertanian digunakan petani sebagai pendapatan tambahan untuk memenuhi kebutuhan rumah tangga sehari-hari.

Tabel 5 menunjukkan rata-rata pendapatan rumah tangga petani padi yang berasal dari usahatani padi sebesar Rp18.806.536,92 dengan 43,04 persen, pendapatan usahatani lain sebesar Rp17.154.076,92 dengan 39,25 persen dan pendapatan luar pertanian sebesar Rp7.734.000,00 dengan 17,70 persen yang berarti rumah tangga petani padi masih bergantung pada sumber pendapatan rumah tangga sektor pertanian. Hasil perhitungan rata-rata total pendapatan rumah tangga petani padi diperoleh sebesar Rp43.694.613,85 per tahun. Rata-rata pendapatan rumah tangga petani padi dalam satu bulan sebesar Rp3.641.217,82.

\section{KESIMPULAN}

Risiko produksi padi petani di Kampung Simpang Asam Kecamatan Banjit termasuk dalam kategori rendah dengan nilai CV sebesar 0,23. Pendapatan rumah tangga petani padi sebesar Rp43.694.613,85 per tahun yang terdiri dari pendapatan pertanian utama 43,04 persen, pendapatan pertanian lain sebesar 39,25 persen, dan pendapatan luar pertanian sebesar 17,70 persen.

\section{DAFTAR PUSTAKA}

BPS [Badan Pusat Statistik] Kabupaten Way Kanan. 2017. Kabupaten Way Kanan Dalam Angka 2017. http//waykanankab. bps.go.id [19 Oktober 2017].

Indah LSM, Zakaria WA, dan Prasmatiwi FE. 2015. Analisis efisiensi produksi dan pendapatan usahatani padi sawah pada lahan irigasi teknis dan lahan tadah hujan di Kabupaten Lampung Selatan. JIIA, 3 (3): 230-234. https://jurnal.fp.unila.ac.id/index.
php/JIA/article/view/1046/951

Desember 2018].

Indriani Y. 2015. Gizi dan Pangan. CV Aura Utama Raharja. Bandar Lampung.

Kadarsan HW. 1995. Keuangan Pertanian dan Pembiayaan Perusahaan Agribisnis. Gramedia Pustaka Utama. Jakarta.

Kementerian Pertanian Republik Indonesia. 2016. Statistik Pertanian 2016. http://epublikasisetjenpertaniango.Id/ download/file/281statistik-pertanian-2016. [19 Oktober 2017]

Lumintang FM. 2013. Analisis pendapatan petani padi di Desa Teep Kecamatan Langowan Timur. Jurnal EMBA, 1 (3): 991-998. https ://ejournalunsrat.ac.idindex.php/emba/search / authors /view2304. [22 Oktober 2017].

Nopralita, Abidin Z, dan Affandi MI. 2017. Dampak el nino terhadap pendapatan rumah tangga petani padi di Kecamatan Punggur Kabupaten Lampung Tengah. JIIA, 5 (2): 181-183. https://jurnal.fp.unila.ac.id/ index.php/JIA/article/view/1656/1482 [30 November 2018].

Pangaribuan IH. 2016. Faktor-faktor yang mempengaruhi risiko produksi padi metode System Of Rice Intensification (SRI) di Desa Nagrak Utara. Sukabumi. Skripsi. Institut Pertanian Bogor. Bogor. http://repository.ipb.ac.id/jspui/bitstream/12 3456789/86225/1/H16ihp.pdf. [30 Oktober 2017].

Rahim A dan Hastuti DRD. 2008. Ekonomika Pertanian (Pengantar, Teori, dan Kasus). Penebar Swadaya. Jakarta.

Sarianti T. 2012. Analisis faktor dan proses pengambilan keputusan pembelian beras organik serta analisis pendapatan dan risiko produksi padi organik. Prosiding Seminar Penilitian Unggulan. Departemen Agribisnis Institut Pertanian Bogor. Bogor.

Soekartawi. 1995. Analisis Usahatani. UI Press. Jakarta. 